\title{
A sexing protocol for wild ruminants based on PCR amplification of amelogenin genes AMELX and AMELY (short communication)
}

\begin{abstract}
Based on the sequences of the bovine amelogenin genes, we have designed a protocol for sexing DNA samples of wild ruminants. Basically the protocol consists on the co-amplification of two specific fragments, one from Ychromosome and one for the $\mathrm{X}$ chromosome, making the use of a PCR control unnecessary. It has been demonstrated to be useful for sex identification in a total of 164 samples belonging to six different wild ruminant species. We propose adding to the census procedure commonly based in faecal groups counting, the faecal sampling and application of the protocol design here, to estimate the sex ratio.
\end{abstract}

Key Words: Sexing, PCR, amelogenin, wild ruminants

\section{Zusammenfassung}

Titel der Arbeit: Ein sexing Protokoll für wildlebende Wiederkäuer, basierend auf einer PCR Verstärkung der amelogenin Gene AMELX und AMELY (Kurzmitteilung)

Es wurde ein Protokoll für die Geschlechtsbestimmung von DNA-Proben bei wildlebenden Wiederkäuern erstellt. Dieses beruht auf den Sequenzen von Bovine-Amelogenin Genen. Grundsätzlich besteht das Protokoll aus der Verstärkung von zwei spezifischen Fragmenten, eines vom Y-Chromosom und ein anderes vom X-Chromosom. Somit wird der Einsatz von PCRKontrollen überflüssig. Diese Vorgehensweise hat sich, bei der Geschlechtsbestimmung von 164 Proben, die zu sechs verschiedenen Wiederkäuerarten gehörten, als sinnvoll erwiesen. Wir empfehlen den Einsatz des erstellten Protokolls, bei Losungs-Stichproben zur Populationserfassung, um das Geschlechtsverhältnis zu bestimmen.

Schlüsselwörter: Geschlechtsbestimmung, PCR, amelogenin, wildlebende Wiederkäuer

\section{Introduction}

Sex identification of unknown samples is useful for natural population managing, allowing the knowledge of the sex ratio. In mammals females are the homogametic sex and have two copies of the $\mathrm{X}$ chromosome. Males are the heterogametic sex and have only one copy of the $\mathrm{X}$ chromosome and one copy of the $\mathrm{Y}$ chromosome. Different approaches, based on PCR methods, have been used in order to determine the sex. Some of the existing protocols are only based on the PCR-detection of Y chromosome specific sequences, such as genes: SRY (TAKAHASHI et al., 1998; MARA et al., 2004), and TSPY (LEMOS et al., 2005); or repeated sequences (SCHROEDER et al., 1990; BREDBACKA and PEIPPO, 1995; KAGEYAMA et al., 2004). The presence of no signal does not necessarily mean that the sample has a female origin, because experimental errors can also lead to negative results. Then, sexing protocols also need a PCR product being out of the Y chromosome, as a positive control of template (DNA) in the sample, or an X chromosome specific fragment. 
In mammals, the amelogenin (AMEL) genes are present on both $\mathrm{X}$ and $\mathrm{Y}$ chromosomes. Amelogenin genes have been used for PCR sex typing test in humans Bovines and deers, because of the difference in length of PCR products from the X and Y chromosomes (SULLIVAN et al., 1993; ENNIS and GALLAGHER, 1994; YAMAUCHI et al., 2000; PFEIFFER and BRENIG, 2005). In this work, we tried to design a protocol based on the simultaneous amplification of amelogenin genes as a method to assign sex to unknown samples of any ruminant species.

\section{Material and Methods}

\section{Samples}

Samples with known sex (male and female) from the following ruminant species have been used to design the sexing protocol: cattle (Bos taurus), sheep (Ovies aries), goat (Capra hircus), roe deer (Capreolus capreolus), Spanish ibex (Capra pyrenaica), chamois (Rupicapra rupicapra), fallow deer (Dama dama), red deer (Cervus elaphus) and mouflon (Ovis musimon). Further, the sexing protocol has been tested in a total of 164 samples belonging to the following species: roe deer (109), fallow deer (15), red deer (12), chamoise (10), Spanish ibex (10) and mouflon (8).

\section{DNA isolation}

A piece of muscle or skin was collected from hunted animals with known sex, and stored in 96\% ethanol. Total blood was collected from domestic ruminants. Total DNA was isolated from, both muscle and skin, following the manufactured instruction of the Nucleo Spin ${ }^{\circledR}$ (Macherey-Nagel) commercial kit.

Simultaneous PCR amplification of amelogenin genes

We used a single pair of primers based on the bovine sequences previously described in ENNIS and GALLAGUER (1994). Amelogenin amplification was carried out in 10 $\mu \mathrm{l}$ containing $25 \mathrm{ng}$ of DNA, $2 \mathrm{mM}$ of each dNTP, $0.2 \mu \mathrm{M}$ of the primers amel-up ( 5'Cy5-CAGCCAAACCTCCCTCTGC-3') and amel-dn (5'CCCGCTTGGTCTTGTCTGTTGC-3'), 2 mM $\mathrm{MgCl}_{2}$, 10x buffer (Biotools, SA), and $0.2 \mathrm{u}$ Taq polymerase (Biotools, SA). The PCR protocol consisted on a first denaturing step at $95^{\circ} \mathrm{C}$ for $5 \mathrm{~min}$, followed by 35 cycles of $95^{\circ} \mathrm{C}$ for $30 \mathrm{sec}, 60^{\circ} \mathrm{C}$ for $30 \mathrm{sec}$, and $72^{\circ} \mathrm{C}$ for $30 \mathrm{sec}$. Final extension was at $72^{\circ} \mathrm{C}$ for $10 \mathrm{~min}$. One of these primers (amelup) was labelled in 5' with a Cy5 fluorocrome. Once the PCR method was performed, the product was electrophoresed in an AlfExpress II semi-automated sequencer system.

In order to confirm sexing results we also used a common protocol based on the SRY gene (see as examples: TAKAHASHI et al., 1998; PHUA et al., 2003). Primers SRYup (5'-CTGCTATGTTCAGAGTATTG-3') and SRY-dn (5'TCAATATTGAACATAAGCGC-3') were designed based on the ovine SRY sequence (accession number AY604733, MEADOWS et al., 2004). SRY amplification was carried out in $10 \mu \mathrm{l}$ containing $25 \mathrm{ng}$ of DNA, $2 \mathrm{mM}$ of each dNTP, $0.5 \mu \mathrm{M}$ of the primers SRY-up and SRY-dn, 2 mM MgCl2, 10x buffer (Biotools, SA), and 0.2 u Taq polymerase (Biotools, SA). The PCR protocol consisted on a first denaturing step at 
$95^{\circ} \mathrm{C}$ for $5 \mathrm{~min}$, followed by 35 cycles of $95^{\circ} \mathrm{C}$ for $30 \mathrm{sec}, 50^{\circ} \mathrm{C}$ for $30 \mathrm{sec}$, and $72^{\circ} \mathrm{C}$ for $30 \mathrm{sec}$. Final extension was at $72^{\circ} \mathrm{C}$ for $10 \mathrm{~min}$.

\section{Results}

As expected from the bovine sequence, a 271 bp product, representing amplification from the $\mathrm{X}$ chromosome amelogenin, was detected for the cow. For the bull, we detected the $271 \mathrm{bp}$, representing $\mathrm{X}$ chromosome, and a new $211 \mathrm{bp}$ band, representing specific Y chromosome amelogenin amplification.

Samples with known sex from some domestic (sheep and goat) and several wild ruminants (roe deer, Spanish ibex, chamois, fallow deer, red deer, mouflon) were used under the same conditions of amplification. All female samples showed one product and all male samples showed two bands. In this case, we found that the presumable Xproduct was 255 bp long, instead of 271 bp long as in the cow. Differences in size of the X-product have already been referenced in sika deer in other studies (YAMAUCHI et al., 2000). The presumable Y-product was 211 bp long in all the tested species except for red deer, which PCR-product was 205 bp long (Fig.).

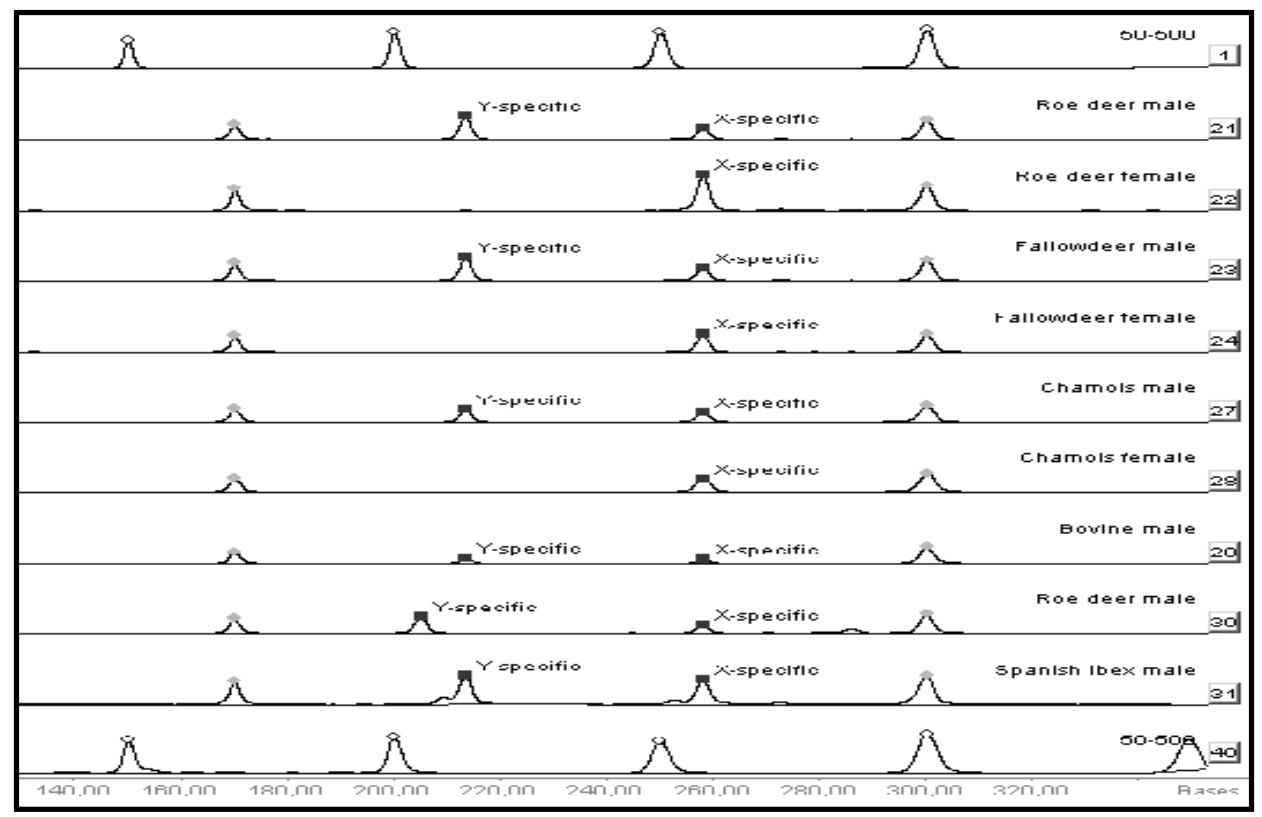

Figure: PCR amplification of the amelogenin gene fragments. Alf Express II gel image. Horizontal lines 1 and 40 represent external size markers. Light dots represent internal size markers. Squares represent PCR products, on the right $\mathrm{X}$-specific amelogenin gene, and on the left $\mathrm{Y}$-specific amelogenin genes. Samples 1, 3, 5, 7, 8, and 9 are males, and samples 2, 4, 6 are females (Amplifizierung der Amelogenin-Gen Fragmente. Alf Express II Gel Image. Horizontale Linien 1 und 40 stellen die externen grössten Marker dar. Helle Punkte stellen die internen grössten Marker dar. Die Kästchen stellen die PCR-Produkte dar, rechts die X-spezifischen Amelogenin-Gene und links die Y-spezifischen Amelogenin-Gene. Proben 1, 3, 5, 7, 8 und 9 sind Männchen und Proben 2, 4, 6 sind Weibchen)

The protocol presented here was used to correctly assign sex to 164 samples of different species of wild ruminants with unknown sex. We obviously detected Xspecific product in all the samples, and 102 of them also showed another band representing the Y-specific product. These samples were assigned the male sex. These 
results were consistent with those of the SRY protocol (not shown). Results of sexing by species are shown in the Table.

Table

Sexing results found in the different wild ruminant species under study (Ergebnisse der Geschlechtsbestimmung bei den untersuchten Wiederkäuerarten)

\begin{tabular}{cccc}
\hline Species & Samples & Males & Females \\
\hline Roe deer & 109 & 80 & 29 \\
Fallow deer & 15 & 5 & 10 \\
Red deer & 12 & 5 & 7 \\
Chamoise & 10 & 4 & 6 \\
Spanish Ibex & 10 & 4 & 6 \\
Mouflon & 8 & 4 & 4 \\
\hline Total & 164 & 102 & 62 \\
\hline
\end{tabular}

\section{Discussion}

We have established a simple and accurate method to determine the sex of unknown wild ruminant samples based on a PCR method, using bovine amelogenin primer sequences. Moreover, this method can also be applied to other domestic ruminant species other than bovine, whose sequence was used to design this protocol.

The major advantage of this method is the co-amplification, in a single tube, of two specific fragments, one from $\mathrm{Y}$-chromosome and one for the $\mathrm{X}$ chromosome, using a single primer pair, and making the use of a PCR control unnecessary. This protocol has been demonstrated to be useful in all the species tested, and has already been used in recent works for roe deer sexing (ROYO et al., 2007). In this work we have used samples from muscle or skin from all the wild ruminants hunted in the Iberian Peninsula, either natives like roe deer, fallow deer, red deer, chamoise and Spanish ibex, or reintroduced like mouflon. Then, this protocol can be used as a tool for sex identification in population managing in game preserves, at least, in most Mediterranean areas.

The sex ratio knowledge is an important parameter for managing of natural populations. One of the most used method to estimate population number is the faecal counting method (AULAK and BABINSKA-WERKA, 1990). The development of this protocol, allow us to propose adding to the common faeces counting pellet groups procedure for census, the faecal sampling and after DNA isolation, the application of the protocol. This can lead to the inclusion of the estimation of the sex ratio into the census method.

\section{Acknowledgements}

This study was partially funded by a grant from MEC-FEDER, no. CGL200503761/BOS. The authors are indebted to the members of Asociación del Corzo Español (http://www.corzo.info/elcorzo/index.php), for their help in sampling and their kind support. We also thank Juan Garrote Haigermoser for his help in German translation.

\section{References}

AULAK, W.; BABINSKA-WERKA, J.:

Estimation of roe deer density based upon the abundance rate of disappearance of their faeces in the forest. Acta Theriol. 35 (1990), 111-120 
BREDBACKA, P.; PEIPPO, J.:

PCR-sexing of bovine embryos: a simplified protocol. Theriogenology 44 (1995), 167-176

ENNIS, S; GALLAGHER, T.F.:

A PCR-based sex-determination assay in cattle based on the bovine amelogenin locus. Anim. Genet. 25 (1994), 425-427

KAGEYAMA, S; YOSHIDA, I.; KAWAKURA, K.; CHIKUNI, K.:

A novel repeated sequence located on the bovine $\mathrm{Y}$ chromosome: its application to rapid and precise embryo sexing by PCR. J. Vet. Med. Sci. 665 (2004), 509-514

LEMOS, D.C.; LOPES RIOS, A.F.; CAETANO, L.C.; LOBO, R.B.; VILA, R.A.; MARTELLI, L.;

TAKEUCHI, P.L.; RAMOS, E.S.:

Use of TSPY gene for sexing cattle. Genet. Mol. Biol. 28 (2005), 117-119

MARA, L.; PILICHI, S.; SANNA, A.; ACCARDO, C.; CHESSA, B.; CHESSA, F.; DATTENA, M.; BOMBOI, G.; CAPPAI, P.:

Sexing of in vitro produced ovine embryos by duplex PCR. Mol. Reprod. Dev. 69 (2004), 35-42

MEADOWS, J.R.S.; HAWKEN, R.J.; KIJAS, J.W.:

Nucleotide diversity on the ovine Y chromosome. Anim. Genet. 35 (2004), 379-385

PFEIFFER, I.; BRENIG, B.:

$\mathrm{X}$ - and Y-chromosome specific variants of the amelogenin gene allow sex determination in sheep (Ovis aries) and European red deer (Cervus elaphus). BMC Genetics, 6 (2005), 16

PHUA, A.C.Y.; ABDULLAH, R.B.; MOHAMED, Z.:

A PCR-based sex determination method for possible application in caprine gender selection by simultaneous amplification of the Sry and Amel-X genes. J. Reprod. Dev. 49 (2003), 307-311

ROYO, L.J.; PAJARES, G.; ÁLVAREZ, I.; FERNÁNDEZ, I.; GOYACHE, F.:

Genetic variability and differentiation in the Spanish roe deer (Capreolus capreolus) characterized via mitochondrial DNA and microsatellite markers: a phylogeographic reassessment in the European framework. Mol. Phyl. Evol. 42 (2007), 47-61

SCHRODER, A.; MILLER, J.R.; THOMSEN, P.D.; AVERY, B.:

Sex determination of bovine embryos using the polymerase chain reaction. Anim. Biotechnol. 1 (1990), 121-133

SULLIVAN, K.M.; MANNUCCI, A.; KIMPTON, C.P.; GILL, P.:

A rapid and quantitative DNA sex test: fluorescence-based PCR analysis of X-Y homologous gene amelogenin. Biotechniques 15 (1993), 636-641

TAKAHASHI, M.; MASUDA, R.; UNO, H.; YOKOYAMA, M.; SUZUKI, M.; YOSHIDA, M.C.; OHTAISHI, N.:

Sexing of carcass remains of the Sika deer (Cervus nippon) using PCR amplification of the Sry gene. J. Vet. Med. Sci. 60 (1998), 713-6

YAMAUCHI, K.; HAMASAKI, S.; MIYAZAKI, K.; KIKUSUI, T.; TAKEUCHI, Y.; MORI, Y.:

Sex determination based on fecal DNA analysis of the Amelogenin gene in Sika Deer (Cervus nippon). J. Vet. Med. Sci. 62 (2000), 669-671

Received: 2006-06-16

Accepted: 2007-07-25

Authors' addresses

GERARDO PAJARES

Asociación del Corzo Español. Paseo de la Habana 187, E-28036, MADRID. SPAIN

ISABEL ÁLVAREZ, IVÁN FERNÁNDEZ, FÉLIX GOYACHE, LUCÍA PÉREZ-PARDAL, LUIS J. ROYO*, PhD,

Área de Genética y Reproducción Animal, SERIDA-Somió, C/ Camino de los Claveles 604, E-33203 GIJÓN (ASTURIAS), SPAIN

*Corresponding Author

E-Mail: ljroyo@serida.org 